GU J Sci, Part C, 5(4): 35-45 (2017)

Gazi Üniversitesi
Fen Bilimleri Dergisi
PART C: TASARIM VE TEKNOLOJI
dergipark.gov.tr/http-gujsc-gazi-edu-tr

\title{
Sağlık Sektöründe Çalışanların İş Sağlığı ve Güvenliğine Dair Bulgularının Yarı Nicel Değerlendirilmesi
}

\author{
Handan AKARSU
}

T.C. Çalışma ve Sosyal Güvenlik Bakanlı̆̆l, Çalışma ve Sosyal Güvenlik Eğitim ve Araştırma Merkezi

\begin{abstract}
$\ddot{O} z$
Makale Bilgisi

Başvuru: 20/03/2017

Düzeltme: 25/07/2017

Kabul: 20/08/2017

Anahtar Kelimeler

Sağllk sektörü

İs sağllğ ve güvenliğ $\mathrm{i}$

Tehlike ve risk

Bu çalışmada doğrudan tıp hizmetlerinde çalışanların işyerinde sağlık ve güvenlikle ilgili tehlikelere ve risklere ilişkin görüşlerinin belirlenmesi amacıyla çalışanların görüşleri alınarak yarı nicel bir çözümleme yapıldı. Böylece belirlenen tehlikeler ve riskler ile uygun öneriler değerlendirildi. $\mathrm{Bu}$ araştırma Ocak-Mart 2015 tarihleri arasında Ankara ilinde Sağlık Bakanlığı'na bağlı, 227 sağlık çalışanı olan, 97 yataklı bir devlet hastanesinde doğrudan tıp hizmeti veren birimlerden gönüllülük esasına göre belirlenmiş 22 katılımcı ile görüşmeler yapılarak gerçekleştirildi. Görüşler, veri toplama aracı olarak yazar tarafından geliştirilmiş yarı yapılandırılmış görüşme formunda bulunan sorular bireysel olarak yüz yüze sorularak alınan cevaplarla sağlandı. Verilerin analizinde tanımlayıcı çözümleme tekniği kullanıldı. Çalışmaya katılan sağlık çalışanlarının cevapları çalışılan birimler temelinde ve genel olarak değerlendirildi. Katılımcıların birimlerinde karşılaştıkları birçok tehlikenin ve riskin farkında olduğu belirlenmiştir. Bütün birimlerde şiddet ve enfeksiyon en çok farkındalığın olduğu riskler olarak tanımlanmış, çoğu katılımcının kas iskelet sistemi rahatsızlıkları yaşadığı belirlenmiştir.
\end{abstract}

Keywords

Health sector

Occupational health and

safety, hazard and risk

\section{Semi Quantitative Evaluation of the Workers' Findings About Health and Safety in Health Sector}

\begin{abstract}
In this study a semi-quantitative analysis was done in order to determine the views of workers who work in direct medical services related to health and safety hazards and risks in the workplace by receiving the opinions of those workers. Thus, appropriate suggestions with determined hazards and risks were evaluated. This research was performed from January to March 2015 in Ankara with 22 participants who were choosen by voluntary basis from the direct medical service units in a public hospital affiliated to Turkish Ministry of Health that has 227 health worker and 97 beds. Opinions were received by asking the questions that are in a semi structured interview form, which was developed by the author as a data collection tool, individually and face to face. . Descriptive analysis technique was used to analyze the data. The answers were evaluated in two ways: separately for each and totally. It was determined that the participants were aware of several hazards and risks in their units. Also in all the units violence and infection were described as risks that has the most heightened awareness and it was determined that most of the participants were suffered from musculoskeletal diseases.
\end{abstract}

\section{GİRIŞ (INTRODUCTION)}

Ekonominin temel sektörlerinden biri olan sağlık hizmetleri sektörü toplum ve insan için sağlık hizmetleri üretilen emek ve teknoloji yoğun bir sektördür. Sağlik hizmetleri koruma, tedavi ve rehabilitasyon hizmetlerini kapsar. Ayrıca, bu hizmetlerin verilebilmesi için çeşitli destek hizmetleri bulunur. Sağlık hizmetlerinde çalışanların tümü kısaca sağlık çalışanları olarak adlandırılır. Sağlık çalışanlarının hizmet sektöründeki sayısal çokluğu ve çeşitliliği dünyada olduğu gibi Türkiye'de de her geçen gün artmaktadır [1]. Türkiye İstatistik Kurumu'nun 2014 verilerine [2] göre Türkiye'de 1,528'i hastane olarak hizmet veren 30,176 sağlık kurumu ve 760,322 sağlı çalışanı vardır.

Sağlık hizmetleri, İşkolları Yönetmeliğinde* 17 numaralı "Sağlık ve Sosyal Hizmetler" başlığı ve alt başlıkları altında yer alır ve birçok işkolu ile meslek grubunu kapsar [3]. Sağlık hizmetleri, sağlık hizmeti 
üretimine doğrudan katılan sağlık meslekleri profesyonelleriyle, hizmet üretimini destekleyen teknik hizmet ve destek hizmet profesyonellerinden oluşan bir ekip tarafından yürütülür. Temel sağlik hizmetlerinin üretildiği tipik bir hastane, tıp hizmetleri ve destek hizmetleri olmak üzere iki bölüme ayrılır. Tıp hizmetleri, tanı, tetkik, tedavi ve danışmanlık işlerini içeren doğrudan tıp hizmetleri ile eczane ve diyet bölümleri gibi yardımcı tıp hizmetlerini kapsar. Destek hizmetleri ise idari ve teknik destek hizmetlerinden oluşur. Verilen hizmetlerin çeşitliliği sağlık çalışanları için birçok fiziksel, kimyasal, biyolojik, ergonomik, güvenlik ve psikososyal tehlike ve riski de beraberinde getirir [4]. Nitekim sağlik sektörü işyeri tehlike sınıfları listesinde ${ }^{1 *}$ çok tehlikeli sınıfta yer alır [5]. Sağlık çalışanları yüksek risk altında çalışıyor olmasına rağmen Sosyal Güvenlik Kurumu'nun (SGK) 2014 y1lı istatistiklerinde sağlık çalışanlarının yaşadığı iş kazası sayısı 2,006, meslek hastalığı sayısı 1 , sürekli iş göremezlik sayısı 1 , ölüm sayısı ise 1 olarak yer almıştır [8]. Ülkemizde iş kazaları ve meslek hastalıkları ile ilgili kayıt ve bildirim yetersizlikleri, sağlık çalışanlarının çoğunluğunun devlet memuru olması nedeniyle kayıt tutulmaması gibi nedenlerle bu sayıların gerçekte daha fazla olduğu düşünülmektedir [1].

Hastanelerde yürütülen hizmet nedeniyle ortaya çıkan sağlık bozuklukları, yaralanmalar ve hastalıklar hem çalışanların acı çekmesine hem de yüksek maliyetlere neden olur. Bunların önlenmesi için mesleki sağlık ve güvenlik önlemleri ve sağlığı geliştirme faaliyetleri yürütülmesi gerektiği bildirilmiştir. Çalışanlar kendi çalışma alanlarını en iyi bilen kişilerdir. Dolayısıyla, çalışanların bu faaliyetlere sürekli katılımının sağlanması önerilmiştir. Hastanelerdeki sağlık ve güvenlik riskleri ile ilgili çalışanların deneyimlerinden faydalanılması, görevlerin tanımlanması, çalışma ortamının ve çalışma alanlarındaki faaliyetlerin geliştirilmesi için çalışanların fikirlerinin alınması gerektiği rapor edilmiştir [6].

29 Aralık 2012 tarih ve 28512 sayılı İş Sağlığı ve Güvenliği Risk Değerlendirmesi Yönetmeliğinin*** 18. Maddesinde "Çalışanların görüşlerinin alınması ve katılımlarının sağlanması" başlığı altında sağlık ve güvenlikle ilgili çalışmalara çalışanların katılımının sağlanması ile ilgili hükümler yer alır [7].

Hastanelerde farklı meslek gruplarındaki çalışanlar farklı hizmet basamaklarında sağlık hizmetinin gereği olarak bir ekip hizmeti yürüterek çalışırlar. Çalışma ortamında farklı meslek gruplarında ve birimlerde görev yapan çalışanların tümünün maruz kaldığı ortak tehlikelerin yanı sıra meslek gruplarına ve birimlere özel tehlikeler de vardır. Özellikle doğrudan hasta bakım hizmetlerinin yürütüldüğü birimlerde çalışanlar yüksek risk altında çalışırlar. Nitekim 2015 yılında bir hastanede yapılan bir risk değerlendirmesi çalışmasında doğrudan sağlık bakımını üstlenen çalışanların yüksek risklere maruz kaldığı ortaya konulmuştur [4]. Bu çalışmada doğrudan hasta bakımı hizmetlerinin verildiği "doğrudan tıp hizmetleri” birimlerinde görev yapan sağlık çalışanlarının sağlık ve güvenlik ile ilgili görüşleri alınarak yarı nicel değerlendirme yapılmıştır.

\section{YÖNTEM (METHOD)}

Bu araştırma Ocak-Mart 2015 tarihleri arasında Ankara ilinde Sağlık Bakanlığı'na bağlı, 227 sağlık çalışanının çalıştığ 1,97 yatağı olan bir devlet hastanesinde doğrudan tıp hizmetlerinde çalışanların sağlık ve güvenlik ile ilgili görüşlerini belirlemeye yönelik yarı nicel bir çalışmadır. Araştırma, durum saptamaya yönelik betimsel bir çalışma olup, nitel araştırma teknikleri temel alınarak tasarlanmıştır.

\section{BULGULAR [FINDINGS)}

\footnotetext{
Ayrıntılı bilgi için bakınız:

${ }^{1}$ http://www.resmigazete.gov.tr/eskiler/2012/12/20121219-8.htm

${ }^{11}$ İş Sağlığı ve Güvenliğine İlişkin İşyeri Tehlike Sınıfları Tebliğinde Değişiklik Yapılmasına Dair Tebliğ

http://www.resmigazete.gov.tr/eskiler/2013/03/20130329-4.htm

${ }^{111}$ http://mevzuat.basbakanlik.gov.tr/Metin.Aspx?MevzuatKod=7.5.16925\&Mevzuatlliski=0\&sourceXmISearch=
} 
Araştırmanın örneklemi için hastanenin doğrudan tıp hizmeti veren birimlerinde çalışanlardan 22 kişi rasgele seçilmiştir. Örneklemdeki katılımcıların özellikleri Tablo 1, Tablo 2 ve Tablo 3 'te verilmiştir.

Tablo 1. Katılımcıların cinsiyet ve öğrenim durumları (Ankara, Mart 2015)

\begin{tabular}{llll} 
& Kategori & Sayı (N) & Yüzde (\%) \\
\hline \multirow{2}{*}{ Cinsiyet } & Erkek & 9 & 40,91 \\
\cline { 2 - 4 } & Kadın & 13 & 59,09 \\
\hline \multirow{2}{*}{$\begin{array}{l}\text { Öğrenim } \\
\text { Durumu }\end{array}$} & Lise & 2 & 9,1 \\
\cline { 2 - 4 } & Ön lisans & 4 & 18,18 \\
\cline { 2 - 4 } & Lisans ve üstü & 16 & 72,72 \\
\cline { 2 - 4 } & Toplam & 22 & 100 \\
\cline { 2 - 3 } & &
\end{tabular}

Tablo 2. Katılımcıların yaş aralıklarının (Ankara, Mart 2015)

\begin{tabular}{lll} 
Yaş aralığ & Sayı $(\mathrm{N})$ & Yüzde (\%) \\
\hline $20-34$ & 8 & 36,36 \\
\hline $35-49$ & 13 & 59,1 \\
\hline $50-61$ & 1 & 4,54 \\
\hline Toplam & 22 & 100 \\
\hline
\end{tabular}

Tablo 3. Katılımcıların meslek grupları ve çalıştıkları birimler

\begin{tabular}{llll} 
& Kategori & Sayı $(\mathrm{N})$ & $\begin{array}{l}\text { Yüzde } \\
(\%)\end{array}$ \\
\hline \multirow{3}{*}{ Meslek } & Hekim & 10 & 45,45 \\
\cline { 2 - 4 } & Hemşire & 7 & 31,81 \\
\cline { 2 - 4 } & $\begin{array}{l}\text { Teknisyen/Sağlik } \\
\text { memuru }\end{array}$ & 3 & 13,63 \\
\cline { 2 - 4 } & Fizyoterapist & 1 & 4,54 \\
\hline \multirow{3}{*}{ Bölümler } & Acil Servis & 3 & 13,63 \\
\cline { 2 - 4 } & Poliklinikler & 9 & 40,91 \\
\cline { 2 - 4 } & Klinik & 6 & 61,18 \\
\cline { 2 - 4 } & Ameliyathane & 3 & 13,63 \\
\cline { 2 - 4 } & Fizik tedavi & 1 & 4,54 \\
\hline & Toplam & 22 & 100 \\
\hline
\end{tabular}

\section{Verilerin toplanması ve analizi (Data Collection and Analysis)}

Araştırmanın verileri yarı yapılandırılmış görüşme tekniği ile toplanmıştır. Araştırmanın amacı dikkate alınarak araştırmacı tarafından geliştirilen yarı yapılandırılmış görüşme formu hazırlanmıştır. Görüşme 
formundaki sorular hazırlandıktan sonra 7 sağlık çalışanı ile ön uygulama yapılmış, ön uygulama sonuçları ve konu ile ilgili deneyimlerinden dolayı görüşme formunun nihai hali sağlık sektöründe iş sağlı̆̆1 ve güvenliği alanında uzman olan Sayın Dr. Bülent Piyal ile birlikte düzenlenmiştir. Görüşme formunda katılımcıların çalıştıkları birim, yaş, eğitim durumu, çalışma yılı, günlük ve haftalık çalışma sürelerinin yer aldığ 1 bir satır ve görüşme sırasında sorulan sorular yer almıştır. Görüşmede sorulan sorular aşağıda verilmiştir:

- Biriminizde sağlı̆̆ınızı ve güvenliğinizi etkileyen tehlikeler nelerdir?

- Karşılaştığınız tehlikelerin sağlık ve güvenliğiniz üzerindeki etkileri nelerdir?

- Hastanede bu etkileri önlemek veya azaltmak için uymanız gereken kurallar nelerdir, siz bu kurallara uygun çalışıyor musunuz?

- Karşılaştığınız sağlık ve güvenlik tehlikelerinin zararlı etkilerini önlemek veya azaltmak için alınmış önlemler yeterli mi, değilse alınması gereken ek önlemler nelerdir?

- İşinizle ilgili işe giriş, süreki eğitimler ve iş sağlı̆̆ı ve güvenliği eğitimleri aldınız mı?

- Yazılı sağlık ve güvenlik talimatlarınız var mı, talimatlara uygun çalışıyor musunuz?

- Varsa önerileriniz nelerdir?

Görüşmeye katılan sağlık çalışanlarına ses kaydına izin verip vermeyecekleri sorulmuş, katılımcıların çoğu ses kaydı alınmasını istememiştir. İzin verenler için ses kaydı alınmış, izin vermeyenlerin cevapları görüşme formlarına yazılarak kaydedilmiştir. Ocak-Mart 2015 tarihlerinde hastaneye araştırma için gidilen günlerde çalışmanın yapılacağı birimlerde bulunan çalışanlara görüşmenin amacı ve yöntemi açıklanmış, isim verilmeyeceği anlatılmış; ancak çalışanların bir kısmı görüşmeyi sakıncalı bulmuş ve katılmak istememiştir. Uygulamanın yapıldığı hastanede günün her saatinde hasta yoğunluğu fazla olduğundan çalışanların bir kısmı görüşme için vakit ayıramamıştır. Ayrıca nöbet sistemi ile çalışılması ve çalışanların tümünün aynı anda hastanede bulunmamasından dolayı 22 çalışana ulaşılmıştır. Görüşme sırasında katılımcıların soruları cevaplarken araştırmacıdan etkilenmemesine çalıșılmıș ve görüşme süresi ortalama 20 dakika sürmüştür. Verilerin analizinde, betimsel analiz tekniği kullanılmıştır. Katılımcılara önceden hazırlanmış olan 7 soru bireysel olarak yüz yüze sorulmuş, verilen cevaplar birimler temelinde derlenmiştir.

\section{Poliklinik Görüşmeleri}

Sadece hekimlerin çalıştığı poliklinik bölümündeki görüşmeler enfeksiyon, mikrobiyoloji, genel cerrahi, göğüs hastalıkları, üroloji, psikiyatri, radyoloji ve ortopedi polikliniklerinde yapılmıştır. Toplam 9 hekimle görüşülmüştür. Görüşülen hekimlerden 4'ü erkek 5'i kadındır. Yaş ortalamaları 39; meslekte toplam çalışma süreleri ortalaması 13; uygulama yapılan hastanede çalışma süreleri ortalaması 3,5 yıldır. Radyoloji doktorları haftada 35 saat; diğerleri 40 saat çalıştıklarını belirtmişlerdir. Bütün katılımcılar ayda 2-3 kez hafta sonu 24 saat, hafta içi ise 16 saat nöbet tuttuklarını belirtmişlerdir.

Katılımcıların tümü sağlık ve güvenliklerini etkileyen en önemli tehlikenin fiziksel ve sözlü şiddet olduğunu belirtmiştir. Şiddetin hasta ve hasta yakınları tarafından gösterildiği aşağıdaki şekilde ifade edilmiştir.

"Bir doktor olarak sağlık ve güvenliğimizi etkileyen en önemli tehlike hastaların saldırmasıdır. Her geçen gün bu tür olaylar artıyor. Son yıllarda toplumun hekimlere bakış açısı değişti, daha az sayg1 duyuluyor hekimlere. Sağlık çalışanları ile ilgili toplumsal bir politika belirlenmeli ve insanların sağlık çalışanlarına bakışı değiştirilmelidir. Bu durum mutsuz bir çalışma ortamına, isteksizliğe ve verimsizliğe neden oluyor " (Radyolog hekim, 25 yıl tecrübeli).

"Şiddet sağlık çalışanları ve özellikle doktorlar için çok ciddi bir tehlike ancak hayati tehlike tazminatı gibi bir uygulama yok maalesef. Erken emekli olamıyoruz. İnsan hayatı söz konusu olduğu için kendimizi düşünmeden, herhangi bir önlem almadan müdahale ediyoruz. Toplum bilinçlendirilmeli, idareciler ve devlet görevlileri halkla sağlık çalışanları ile ilgili olumlu görüşlerini paylaşmalılar ve meslek itibarı artırılmalı" ( Genel cerrah, 18 yıl tecrübeli). 
Enfeksiyon, mikrobiyoloji, göğüs hastalıkları ve genel cerrahi bölümlerinde çalışan hekimler enfeksiyonu tehlike olarak belirtmiştir. Genel cerrahide kesici delici alet kullanımı ve yapılan işin sorumluluğu ve riskine göre aşağıda ifade edildiği üzere ücretlerin yetersiz olmasının ve ücretlerde kıdeme göre artış olmaması da tehlike olarak belirtilmiştir.

"Hekim olarak 20 yıl da çalışsak 5 yıl da çalışsan aynı maaşı alıyorsun. Maaş yaptığımız işe göre az" (Genel cerrah, 18 y1l tecrübeli).

Poliklinikte çalışan hekimler tarafından tehlike olarak görülen diğer hususlar ise aşağıda belirtildiği gibi uzun nöbetler, çalışma alanının dar olması, iş yoğunluğunun fazla olması, iş tatmini olmaması, ergonomik olmayan teçhizat, çalışma ortamının kalabalık olması, havalandırmanın yetersiz olması, bazı odalarda pencere olmaması ve radyoloji bölümünde radyasyon ve alerjik lateks eldiven olarak belirtilmiştir.

"Hastanede çalışan iş güvenliği uzmanını tanımıyorum. Çalışma saatlerinin uzun olması çok ciddi bir sorun. Hekim sayısının yeterli olmaması nedeniyle 24 saat nöbet tuttuktan sonra 9 saat daha çalışmak zorunda kaldığım oluyor. Bu hem hekim için hem de hastalar için tehlikeli bir durum. Hastanede personel sayısı artırılmalı" (Ürolog hekim, 9 yıl tecrübeli).

Katılımcılar işyerlerinde bulunan tehlike ve risklerin sonucunda yaşadıkları sağlık sorunlarına stres, baş ağrısı, halsizlik, dikkat dağınıklığı, performans düşüklüğü, lateks alerjisi, bulaşıcı hastalıklar, solunum sistemi enfeksiyonları, mutsuzluk, sinir bozukluğu, sırt ve boyun ağrıları, depresyon cevaplarını vermiştir.

Katılım sağlayan hekimlerin 4'ü beyaz kod uygulamasından bahsetmiş, 2'si kişisel koruyucu donanımları kullanmaları gerektiğini, diğerleri herhangi bir kural olmadığını belirtmiştir.Katılımcıların tümü alınan önlemlerin yeterli olmadığını düşündüklerini söylemiştir. Beyaz kod ve kişisel koruyucu donanımlara ek olarak hekimler hasta ve hasta yakınları ile tartışmaya girmekten kaçındıklarını ifade etmiş̧; hekimlerden biri yanında önlem olarak biber gazı taşıdığını söylemiştir. Katılımcıların tümü aşağıda belirtildiği gibi yalnız çalışmamaları gerektiğini, muayene odasında hemşire ve yardımcı personel ile poliklinik girişlerinde güvenlik personeli bulunması gerektiğini söylemiştir.

"Hastalarla doğrudan temas halindeyiz ve poliklinik bölümünde ayrı bir güvenlik bulunmuyor. Çalışma sırasında da muayene odalarında yalnızız, hemşire ile çalışmıyoruz. Dolayısıyla muayene sırasında hasta ile yalnız kalıyoruz ve herhangi bir olumsuz durumda tanıklık edecek kimse olmuyor yanımızda. Hastane olarak kullanılan bu bina aslında başka bir amaçla öğrenci yurdu olarak yapılmış, bu yüzden odalar çok küçük ve havalandırma yetersiz. Bu durum solunum yolu hastalıklarına, bulaşıcı hastalıklara neden oluyor, evde aileme de sürekli bu hastalıklar bulaşıyor. Çalışma şevki kalmıyor ve baş ağrısı, sinir bozukluğu ve mutsuzluğa neden oluyor. Hastalarla tartışmaya girmemeye çalışıyorum” (Göğüs hastalıkları hekimi, 14 yıl tecrübeli).

Aynı katılımcılarla, şiddetin önlenmesi için hastaların sağlık personeline bakış açılarının değiştirilmesi, meslek itibarının artırılması için çalışmalar yapılması ve toplumun bilinçlendirilmesi gerektiği söylenmiştir. Fiziksel şartlarının iyileştirilmesi, lateks olmayan eldiven verilmesi, pencereli odaların tahsis edilmesi, personel sayısının artırılması, muayene odalarında hasta saldırısı olması ihtimaline karşı ikinci bir çıkış bulunması gerektiği ifade edilmiştir.

Bir katılımcı hariç diğer katılımcılar işle ilgili sürekli eğitimler düzenlendiğini ancak işe girişte eğitim almadıklarını söylemiştir. Katılımcıların tümü iş sağlığı ve güvenliği ile ilgili seminerler düzenlendiğini ancak eğitim verilmediğini söylemiştir. Bir hekim işyeri hekimliği kursuna gittiğini belirtmiştir.Bir hekim yazılı sağlı ve güvenlik talimatı olduğunu söylemiş, diğerleri böyle bir talimattan haberdar olmadıkları cevabını vermiştir. Talimatlardan haberdar olan hekim talimatlara uygun çalıştığını söylemiştir.Işs kazası olarak iğne batması, cilt tahrişleri ve çeşitli kesiler yaşandığı söylenmiştir. İşle ilgili hastalık olarak tansiyon, astım ve solunum yolu hastalıkları söylenmiştir. Binanın değiştirilemeyeceği ama havalandırmanın iyileştirilmesi ve toplumun bilinçlendirilmesi için devletin çalışmalar yapması gerektiği ifade edilmiştir.

\section{Klinikler}


Yataklı servislerde çalışan 5 hemşire ile görüşme yapılmıştır. Poliklinik hekimleri de zaman zaman bu bölümde bulunmaktadır. Genel cerrahi, dahiliye, meslek kliniği, gögüs hastalıkları ve enfeksiyon kliniklerinde görüşmeler gerçekleşmiştir. Görüşülen katılımcıların yaş ortalamaları 36; meslekte toplam çalışma süreleri ortalaması 15, uygulama yapılan hastanede çalışma süreleri ortalaması 9 yıldır. Tüm katılımcılar haftada 40 saat çalışmaktadır ve ayda 2-3 kez hafta sonu 24 saat, hafta içi 16 saat nöbet tutmaktadır. Katılımcıların çoğuna göre en önemli risk sözel şiddettir. Hastalarla ve hasta yakınları ile sık sık tartışmalar yaşandığını ve bunların zaman zaman fiziksel şiddete dönüştüğü belirtilmiştir. Sözel ve fiziksel şiddetin yanı sıra hemşirelere göre dar çalışma alanı, hasarlı ve kaygan zeminler, çalışan sayısının yetersizliği, delici kesici aletler, uzun nöbetler, enfeksiyon, ağır kaldırma-taşıma ve bazı kimyasal maddeler tehlike olarak görülmektedir.Katılımcıların tümü bulaşıcı hastalıklara yakalanma endişesi içindedir. Karşılaşılan tehlikelerin hemşireler üzerinde stres, moral bozukluğu, yorgunluk, dikkat eksikliği, dermatit, kas iskelet sistemi rahatsızlıkları gibi etkileri olduğu bilinmektedir. Atıkların, özelliklerine göre ayrı kaplara atılması, kişisel koruyucu donanımların kullanılması, hijyen kurallarına uyulması gibi işyeri kurallarına uyulması gerektiği belirtilmiştir. Katılımcı bir hemşire:

\footnotetext{
"En sık yaşanan iş kazası iğne batması, benim de başıma geldi. Enfeksiyon hemşiresine durumu bildirdim kan testleri yapıldı, bir sorun yok ama 6 ay 1 sene aralıklarla kontrol ediliyor. Çalışma ortamındaki tehlikelerin en büyük etkisi psikolojik etkiler. İşim dolayısıyla sürekli stres yaşıyorum. Bunun dışında çalışma hayatında kadın olmak stres etkeni. Şu anda çocuğum hasta ve aklım onda. Yaptığım iş gereği hastalarla sürekli iletişim halindeyim ve zamanla bir bağ kuruluyor. Hastaların yaşadığı olumsuz durumlar beni de çok etkiliyor” demiştir (Genel cerrahi, ebe hemşire, 18 yıl tecrübeli).
}

Görüşmeye katılanların ikisi önlemlerin yeterli olduğunu düşünürken, diğerleri yetersiz bulmuştur. Katılımcıların tümü kurallara uygun çalışmaktadır. Katılımcılar çalışan sayısı artırılmalı, fiziksel yapı iyileştirilmeli, güvenlik artırılmalı ve eğitimler artırılmalı görüşündedir. Katılımcıların tümü sürekli eğitimler almaktadır. Son yıllarda yalnızca seminer şeklinde iş sağlığı güvenliği bilgileri verilmektedir.

Hemşirelerden biri kalite dosyalarında bulunan güvenli çalışma talimatlarına zaman zaman baktığını ve bu talimatlara uygun çalıştığını belirtmiştir, katılımcıların çoğu güvenli çalışma talimatlarının olmadığını söylemiştir.Katılımcılar ameliyathanede masa parçasının düşmesi, iğne batması gibi iş kazaları yaşadıklarını ve işle ilgili kas iskelet sistemi hastalıkları ve mide rahatsızlıkları olduğunu söylemişlerdir. Katılımcılara göre, güvenlik artırılmalı, fiziksel şartlar düzeltilmeli, eğitimler artırılmalıdır.

\section{Acil Servis Birimi Görüşmeleri}

Acil servis bölümünde bir doktor, iki hemşire ve bir sağlik memuru ile görüşme yapılmıştır. Katılımcıların yaş ortalaması 37; meslekte toplam çalışma süreleri ortalama 16 yıl, uygulamanın yapıldığı hastanede çalışma süreleri ortalama 4 yıldır. Nöbetler hafta sonu 24 saat, hafta içi 16 saattir. Katılımcıların tümü sağl1k ve güvenliklerini etkileyen en önemli tehlikelerin fiziksel, sözlü şiddet ve enfeksiyon olduğunu belirtmiştir. Fiziksel ve sözlü şiddet olaylarının adli vakalarda veya alkollü hasta geldiğinde daha sık görüldüğünü ifade etmişlerdir. Katılımcılardan bir hekim:

“Acil servisteki en önemli tehlike adli vakalar. Çalışırken sürekli tedirginlik içerisindeyiz. Hasta kaydı ve muayene aynı yerde yapılıyor, hasta ile direkt muhatap oluyoruz. Adli vakalar için ayrı bir yer tesis edilmeli ve mutlaka güvenlik nezaretinde muayene yapılmalı" demiştir (Acil servis hekimi, 15 yıl tecrübeli).

Enfeksiyona ise hastaların öksürmesi sonucu solunum yoluyla veya enjeksiyon iğnesinin batması sonucu maruz kaldıklarını söylemişlerdir. Hekim tarafindan başka bir tehlike görülmezken, hemşirelerden biri iş yoğunluğunun fazla, personel sayısının az olmasının, uzun süre ayakta çalışmanın ve aydınlatmanın rahatsız edici olmasının da sağliklarını etkilediğini söylemiştir. Sağlık memuru ise ek olarak nöbetlerin çok uzun olduğunu ve aydınlatmanın rahatsız edici olduğunu ifade etmiştir.

Bütün katılımcılar şiddet ihtimalinin strese neden olduğunu ve özellikle geceleri çalışırken sürekli tedirgin olduklarını söylemiştir.Hekim kronik yorgunluğa yakalandığını belirtirken; diğer çalışanlar baş ağrısı, agresiflik, yorgunluk yaşadıklarını ve sık sık bulaşıcı hastalıklara yakalandıklarını belirtmişlerdir. 
Bütün katılımcılar şiddet tehlikesine karşı beyaz kod uygulamasından bahsetmiştir. Enfeksiyon tehlikesine karşı ise eldiven, maske, iş kıyafetleri ve bone kullanmak zorunda olduklarını belirtmişlerdir.

Bütün katılımcılar anılan eylemlere karşı alınan önlemlerin yeterli olmadığını düşündüklerini ifade etmiştir. Katılımcılardan tümü sayılan önlemlerin hepsini uyguladıklarını söylemiştir. Önlemleri yeterli bulmayan katılımcılar binanın fiziksel şartlarının iyileştirilmesi, personel eksikliğinin tamamlanması ve enfeksiyonu azaltmak için havalandırmanın iyileştirilmesi gerektiği cevabını vermiştir.Bütün katılımcılar işle ilgili sürekli eğitimler düzenlendiğini söylerken yalnızca iki katılımcı işe girişte eğitim aldığını söylemiştir. Katılımcıların tümü iş sağlığı ve güvenliği ile ilgili seminerler düzenlendiğini ancak eğitim verilmediğini söylemiştir. Yalnız sağlık memuru yazılı sağlıklı ve güvenli çalışma talimatı olduğunu söylemiş̧ir. Diğer katılımcıların konuyla ilgili bilgisi olmadığı gözlenmiştir. Sağlık memuru talimatlara uygun çalıştığını söylemiştir.

Hemşireler ve sağlık memuru iğne batması yaşamıştır. Sağlık memurunun tetkikleri yapılmış ve HepatitB aşısı olmuştur, kontrolleri devam etmektedir. Hekim meslek hastalığı olmadığını; hemşireler ve sağlık memuru migren, bel ve boyun fitı̆̆ hastası olduklarını söylemiştir.Sağlık çalışanlarının güvenliklerinin sağlanması için çalışmalar ve düzenlemeler yapılması, çalışma koşullarının iyileştirilmesinin gerekli olduğu; adli vakalar için ayrı bölümlerin tahsis edilmesinin ve çalışanların doğrudan muhatap olmasının engellenmesinin gerektiği ifade edilmiştir. Katılımcılara göre acil servislere girişlerde güvenlik bulunmalidir.

\section{Ameliyathane Birimi Görüşmeleri}

Ameliyathanede 1 hemşire ve 2 tekniker ile görüşmeler yapılmıştır. Katılımcıların yaş ortalaması 32, toplam çalışma süresi ortalaması 10, uygulamanın yapıldığı hastanede çalışma sürelerinin ortalaması 4 yıldır. Yalnızca hemşire düzenli nöbet tutarken diğer çalışanlar gerektiğinde çağırılmaktadır. Nöbet ve icap dışında haftada 40 saat çalışılmaktadır.

Ameliyathanede çalışan katılımcıların tümü sağlık ve güvenlik riski olarak enfeksiyon cevabını vermiştir. Katılımcılar izole bir ortamda çalışmayı, yetersiz havalandırmayı, anestezik gazları tehlike olarak tanımlamıştır. İki katılımcı bu konuda aşağıdaki beyanlarda bulunmuşlardır:

\footnotetext{
"Standartlara uygun bir çalışma ortamımız yok. 8 saat boyunca kapalı bir ortamdayız, yemeklerimizi bile burada yiyoruz. Kalabalık bir grupla çalışıyoruz ve yeterli dinlenme alanı yok, havalandırma yetersiz. Anestezik gazlara maruz kalabiliyoruz. Bu yüzde sağlıklı beslenmemize özen göstermemiz lazım”(Ameliyathane hemşiresi 21 yıl tecrübeli).
}

\footnotetext{
"Çalışma süresi boyunca bu bölümde kapalı kalıyoruz, sosyal bir çalışma ortamının olmaması sıkıntı ve strese neden oluyor. Ameliyathane çalışanları için de radyolojideki gibi yıpranma payı olmalı radyoloji gibi, daha önce çalıştığım hastanede de bu bölümde kapalı ortamda çalışıyorduk. Ancak dışarıyı görebiliyorduk, kafeteryamız vardı ve masa tenisi oynayabiliyorduk, o zaman bu kadar stres olmuyordu. Fiziki yapı düzeltilemiyorsa çalışanlar için hafta sonu aktiviteleri düzenlenebilir. Ödüllendirme sistemi olmalı ve ekstra izinler verilmeli” (Anestezi teknikeri, 6 y1l tecrübeli).
}

Hemşire gürültü, aydınlatma ve bilgisayarların da sağlık için zararlı olabileceğini söylerken katılımcıların tümü işyerindeki tehlikelerin sağlık etkisi olarak bulaşıcı hastalıklar cevabını vermiştir. Katılımcılar tarafından söylenen diğer etkiler ise halsizlik, depresyon, karaciğer yağlanması, cilt problemleri, korku ve endişedir.Katılımcılara göre, ameliyathaneye günlük kıyafetle girilmesi yasaktır. Mutlaka ameliyathane önlüğü, terliği, bonesi, maskesi ve eldivenler kullanılmalıdır. Enfeksiyon riski oluştuğunda enfeksiyon hemşiresine haber verilmelidir.Teknisyen alınan önlemleri yeterli bulduğunu söylerken diğer katılımcılar yeterli bulmadıklarını belirtmişlerdir. Anestezi teknikeri, izole ortamdan kaynaklanan stresi önlemek için sosyal aktiviteler düzenlenmeli derken diğerleri ek bir önlem önermemiştir.Verilen cevaplara göre yalnız 
anestezi teknikerinin işe giriş eğitimi almış olduğu, diğerlerinin almadığı anlaşılmıştır. Sürekli eğitimlere ise katılımcıların tümü katılmaktadır. Katılımcıların tümü iş sağlığı güvenliği eğitimi almadığını belirtmiştir.Hemşire yazılı 'sağlıklı ve güvenli çalışma talimatı' olduğunu ve talimatlara uygun çalıştığını söylerken diğerleri böyle bir talimattan haberdar olmadıklarını söylemişlerdir. Bütün katılımcılar iğne batması kazası yaşamış, enfeksiyon prosedürü uygulandığını belirtmişler, meslek hastalığı yaşamadıklarını söylemişlerdir. Katılımcılara göre bu konuda eğitimler artırılmalı, ödül sistemi getirilmelidir.

\section{Fizik Tedavi}

Fizik tedavi biriminde 2 fizyoterapist çalışmaktadır. İş yoğunlukları nedeniyle yalnızca biriyle görüşme yapılmıştır. Fizyoterapist haftada 40 saat çalışmaktadır, nöbet tutmamaktadır. Katılımcıya göre çalışma ortamında havasızlık dışında bir tehlike yoktur. Ortamın havasızlığı alerjiye yol açar. Katılımcı çalışırken eldiven kullanılmasının zorunlu olduğunu, alınan önlemlerin yeterli olduğunu ve ek önlem alınmasına gerek olmadığını söylemiştir. Katılımcı işe giriş eğitimi ve sürekli eğitim aldığını ifade etmiştir. İş sağlığı ve güvenliği ile ilgili seminer alınmıştır. Katılımcı yazılı sağlıklı ve güvenli çalışma talimatının mevcut olduğunu ve talimatlara uygun çalışıldığını belirtmiştir. Katılımeı iş kazası ya da meslek hastalığı geçirmediğini söylemiştir.

\section{SONUÇ ve TARTIŞMA (CONCLUSION and DISCUSSION)}

Sağlık hizmetleri içinde temel sağlık hizmetleri kapsamında olan koruyucu sağlık hizmetlerinde ve tedavi hizmetinin yoğunlukta olduğu hastane hizmetlerinde kadınların istihdamı çoğunluktadır [9]. Uygulama yapılan hastanede de bu hizmetlerde kadın çalışan sayısı fazladır. Görüşme yapılan 22 sağlık çalışanından 14'ü kadın 8'i erkektir.

Görüşme kapsamında hekim, hemşire, tekniker ve fizyoterapist ile görüşülmüştür. Amaç, hastanede bulunan doğrudan sağlık bakımı hizmeti veren meslek gruplarının tümünden görüş alınmasıdır. Çalışmanın yapıldığ 1 birimlerde çalışan toplam kişi sayısına göre görüşülen kişi sayısı değişiklik göstermiştir.Katılımcıların çoğu lisans ve lisansüstü öğrenim mezunudur. Doğrudan sağlık hizmetlerinin niteliği gereği, bu mesleklere sahip olmak için ön lisans veya yükseköğrenim mezunu olma zorunluluğundan eğitim seviyesi yüksektir. Katılımcıların çoğu 35-49 yaş aralığındadır ve tecrübeleri fazladır. Katılımcılarda yaş ve tecrübe arttıkça tehlike ve risk bilincinin yüksseldiği gözlenmiştir. Katılımcıların tümü haftalık 40 saat çalışırken fizyoterapist dışında bütün çalışanlar nöbet tutmaktadır. Nöbet tutan katılımcılar tarafından uzun çalışma saatleri tehlike olarak tanımlanmıştır. Görüşmelerle ilgili birimler temelinde elde edilen bulgularla yapılan değerlendirmede aşağıdaki sonuçlar elde edilmiştir.

\section{Poliklinikler}

Polikliniklerde çalışan hekimlerin tamamı şiddeti tehlike olarak tanımlamıştır. Hekimlerin birebir hasta ve hasta yakınları ile muhatap olmaları ve hastaların psikolojik ve fiziksel olarak güçsüz ve hassas olmaları, hasta yakınlarının hastaların sağlı̆̆ ile ilgili olumsuz bir durum yaşandığında hekimi sorumlu görmeleri hekimlere karşı fiziksel ve sözlü şiddetin nedenleri olabilir. Bu durum hekimler için öncelikli ve önemlidir ancak yeterli önlem alınmadığını düşündükleri gözlenmiştir. Görüşmeye katılan hekimler diğer tehlikelerin de farkındadır ancak şiddet kadar önemsememişlerdir. Bunun nedenleri şiddet olaylarının sık yaşanması olabilir. Nitekim Ankara'da 2008 yılında Gazi Üniversitesi Tıp Fakültesi'nde yapılan kesitsel bir araştırmaya göre görev yapan hekimlerin \%60,9'u çalışma yaşamı boyunca iş yerinde şiddetle karşılaşmıştır ve en çok karşılaşılan şiddet tipi duygusal/sözel şiddettir [10]. Diğer tehlike ve risklerin önemsenmemelerinin bir diğer nedeni de hekimlik yaparken kendi sağlıklarını düşünmemeleri, önceliklerinin hastalar olması olabilir. 


\section{Klinikler}

Kliniklerde de hemşireler tarafindan öncelikli görülen tehlike şiddettir. Şiddetin yanı sira özellikle hemşireler için enfeksiyon risk oluşturmaktadır. Bu birimde görüşme yapılan hemşirelerin enfeksiyon riskini çok önemsedikleri ve bu konuda stres yaşadıkları gözlenmiştir. Çünkü katılımcıların tamamı en az bir kez enfeksiyon tehlikesi geçirmiştir. Görüşmeye katılan hemşirelerin de tümü enfeksiyon ile ilgili prosedürlerin uygulandığından bahsetmiştir. Görüşmeye katılan klinik çalışanlarının sağlıklı ve güvenli çalışma talimatlarından haberdar olmamasının nedeni idari önlemlerin yetersiz olması olabilir.

\section{Acil Servis}

Katılımcıların tamamı için acil serviste fiziksel, sözlü şiddet ve enfeksiyon tehlikesi olduğu belirlenmiştir. Fiziksel ve sözlü şiddetin sık görülmesinin nedeni olarak acil servise gelen adli vakalar görülmektedir. Bir diğer neden ise hastaların acil durumda olması nedeniyle hasta yakınlarının psikolojik olarak hassas olmaları olabilir. En çok tehlike ve risk hemşireler tarafından tanımlanmıştır. Acil servisin günün her saatinde yoğun olması ve hemşirelerin iş yükünün fazla olması bu durumun nedeni olabilir. Acil servis çalışanları karşılaştıkları tehlikelerin farkındadır ve alınan önlemleri uygulamaktadır. Hastanede sürekli olarak düzenlenen seminerlere ve eğitimlere katılmalarının ve daha önce geçirmiş oldukları iş kazalarının etkisi olduğu söylenebilir. Ancak meslek hastalıkları olmadığını belirtmeleri ağır meslek hastalıkları vakaları ile karşılaştıklarından kendi rahatsızlıklarını önemsememelerinden ileri gelebilir.

\section{Ameliyathane}

Tüm katılımcıların enfeksiyon cevabı vermesinin nedeni ameliyathanede yaptıkları iş dolayısıyla bütün enfeksiyon etmenleri ile karşılaşmaları olabilir. Bunun dışında psikososyal tehlikelere değinmelerinin sebebi yaptıkları işin hayati olmasından ötürü yaşadıkları stres, izole ortamda çalışmaktan dolayı sosyalleşememeleri, mesai boyunca kapalı bir ortamda ve bölümün herhangi bir yerinde dişarıya açılan bir pencerenin bulunmaması olabilir. Parlar'ın da çalışmasında ifade ettiği gibi[11] katılımcılar tarafından ameliyathane için havalandırmanın yetersiz olduğu ve özel havalandırma gerektirdiği düşünülebilir.

\section{Fizik Tedavi}

Görüşmeye katılan fizyoterapist, sağlık ve güvenliği ile ilgili en önemli tehlikeyi havasızlık olarak tanımlamıştır. Çalışma ortamının küçük olması ve hasta yoğunluğunun fazla olması bu durumun nedeni olabilir. Fizyoterapistin diğer birimlerden farklı olarak çok tehlikeli bir ortamda çalıştığını düşünmediği gözlenmiştir.Görüşmeler farklı birimlerde ve meslek gruplarında yapılmıştır. Ancak birimlerden ve meslek gruplarından bağımsız olarak hemen her katılımcı enfeksiyonu ve şiddeti tehlike olarak gördüğünü söylemiştir. Bu çalışmada da Piyal'in belirttiği gibi[1] sağlık hizmetlerinin bir ekip işi olması nedeniyle meslek grubu ayırt edilmeksizin çalışanların tümü için enfeksiyon ve şiddet ortak tehlike olarak değerlendirilmiştir.Eskişehir-Bilecik Tabip Odası tarafından 2002 yılında yapılan bir çalışmada[12] da sağlık çalışanlarının \%50,8'inin çalıştığı bir anda şiddet türlerinden birine ya da daha fazlasına maruz kaldığı saptanmıştır. Samsunda 2006 yılında Ruh ve Sinir Hastalıkları Hastanesinde 64 sağlık çalışanı (14 hekim, 50 hemşire) ile yapılan bir çalışmada[13] son bir yılda çalışanların herhangi bir şiddete maruz kalma sıklığının \%85,9 olduğu, \%59,4'ünün sözel şiddete, \%26,5'inin fiziksel şiddete maruz kaldığı saptanmıştır.Erzurum Atatürk Üniversitesi tarafından 2005 yılında 386 sağlık çalışanı üzerinde yapılan bir çalışmada[14] ise çalışanların $313(\% 81,1)$ 'ünün bir veya daha fazla enfeksiyon tehlikesi geçirmiş olduğu belirtilmiştir. Bunların \%84,5'inin kan ve kan ürünleri ile, \%3,9'unun vücut sıv1ları ile, $\% 11,6$ 'sının ise diğer materyallerle ilişkili olduğu gözlenmiştir. En sık rastlanan temas şekli \%46,6 ile iğne batması veya kesici/delici alet yaralanmalarıdır.

Sağlık ve güvenlikle ilgili tehlikelerin etkileri sorulduğunda ise şiddetin yol açtığı psikososyal etkiler ve enfeksiyon riskinin yanı sıra görüşme yapılan bütün birimlerde meslek grubu farketmeksizin katılımcıların çoğu baş, boyun, sırt ağrıları gibi kas iskelet sistemi hastalıklarından bahsetmiştir. Yapılan çalışmalara bakıldığında görüşmelerde verilen cevaplarla uyumlu olduğu görülür. Bir çalışmada 331 sağlık çalışanının 227 'si $(\% 68,5)$ bel ağrısı şikâyeti olduğunu, 14'ü $(\% 4,2)$ bel fitığı hastalığg olduğunu 
belirtmiştir [15]. Ülkemizde hekimler üzerinde yapılan bir çalışmaya[16] göre çalışmaya katılan 123 hekimden 41 (\%33)'inde kas iskelet sistemi sorunu olduğu saptanmıştır. Samsun'da dört hastanede yapılan bir araştırmada araştırmaya katılan[17] 305 hekimin \%62'sinin en az bir bölgesinde kas iskelet sistemi rahatsızlığ 1 bulunduğu; en s1k görülen rahatsızlıkların ise bel $(\% 50,3)$, boyun $(\% 49,7)$, sirt $(\% 38,6)$, omuz $(\% 36,5)$ ağrıları olduğu görülmüştür.

Çalışanlarla yapılan görüşmeler sonucu katılımcıların enfeksiyon ve şiddeti daha çok önemsemelerine karşın kimyasallar, radyasyon, kesici delici aletler, iş yoğunluğu, gürültü, yetersiz havalandırma ve benzeri birçok tehlikenin de farkında oldukları anlaşılmıştır. Bu farkındalığın nedenleri:

- Çalışanların çoğunun eğitim seviyelerinin ve mesleki tecrübelerinin yüksek olmas1,

- Hastanenin hizmet verdiği alandan ötürü mesleki sağlık ve güvenlik risklerinin sonuçlarını bizzat görmeleri,

- Yönetim tarafından verilen sürekli eğitimlere katılmaları ve benzerleri olabilir.

Ancak, sağlık çalışanlarının farkında oldukları ve korunmak için hangi önlemleri uygulamaları gerektiğini bildikleri şiddet, kimyasallar, radyasyon gibi tehlikelerin ve ergonomik olmayan koşulların olası etkilerini önemsemedikleri ya da bu tehlikelere ve etkilerine karşı kayıtsız kaldıkları da görülmüştür. Bu tutumun nedenleri ise;

- Sağlık ve güvenlik kültürünün tam anlamıyla yerleşmemesi;

- Sağlık etkilerinin kısa sürede ortaya çıkmaması nedeniyle bu etkileri önemsememeleri;

- Sağlık çalışanlarının kendilerini hastaları iyileştiren; başka bir anlatımla hastalanan değil, hastalananı sağlığına kavuşturan kişiler olarak gördükleri için hastanedeki tehlikelerden etkilenebileceklerine inanmamaları veya etkilenseler bile, kendilerini iyileştirebileceklerini düşünmeleri ve bu nedenle tehlikelere ve olası etkilerine "bize bir şey olmaz" yaklaşımıyla kayıtsız kalmaları,

- Sağlık çalışanlarının tehlikelerden korunmalarını sağlayacak etkili önlemler alınabileceğine inanmamaları ve benzerleri olabilir.

$\mathrm{Bu}$ çalışma sonucu aşağıda yapılan önerilerin bu konunun geliştirilmesinde yararlı olabileceği düşünülmektedir:

- Bu çalışma doğrudan bakım hizmetlerinin dışında sağlık kuruluşlarındaki destek hizmetlerini de içerecek şekilde genişletilmelidir.

- Sağlık kuruluşlarında çalışanların sağlık ve güvenliğinin korunmasında çalışanların görüşleri ve önerileri dikkate alınarak birimlere ya da meslek gruplarına yönelik değil, kuruluşun tümünde bulunan risklerin tümünü önlemeye ya da bu risklerden korunmaya yönelik yerinde, sürekli ve sistematik yaklaşımlar geliştirilmelidir.

- Her sağlık kuruluşunda risk değerlendirilmesi kapsamında çalışanların görüş ve önerilerini almak amacıyla bu tür bir çalışma gerçekleştirilmeli, sonuçları değerlendirilmeli ve risk değerlendirmesi bu çalışmanın sonuçlarına göre güncellenmelidir.

- Bu çalışmalar doğrultusunda hastanede etkili bir sağlık ve güvenlik yönetimi ile çalışanların sağlıklı ve güvenli çalışmasını sağlayacak bütünsel politikalar planlanmalı ve uygulanmalıdır.

\section{KAYNAKLAR (REFERENCES)}

[1]. Piyal B. Y., "Sağlık Çalışanlarının İş Sağlığı ve Güvenliği Sorunlarına Genel Bakış”, Türk Toraks Derneği Yıllık Kongresi, Antalya, s.1-5, (2009). 
[2]. Sağlık Bakanlığı, Sağlık İstatistikleri Yıllığı 2013, Ankara: Sentez Matbaacılık ve Yayıncılık, s.75137, (2014).

[3]. İşkolları Yönetmeliği. T.C. Resmi Gazete, 28502, 19.12.2012. Erişim Tarihi:15.09.2016.http://www.resmigazete.gov.tr/eskiler/2012/12/20121219-8.htm

[4]. AKARSU, H., "Sağlık İşkolunda Tehlike ve Riskler: Bir Hastanede Risk Analizi Uygulaması", Uzmanlık Tezi, Çalışma ve Sosyal Güvenlik Eğitim ve Araştırma Merkezi, Ankara, (2015).http://www.casgem.gov.tr/sayfalar/sayfa/params/tip-kitap/id-93/saglik-iskolunda-tehlike-veriskler-bir-hastanede.html

[5]. İş Sağlığı ve Güvenliğine İlişkin İşyeri Tehlike Sınıfları Tebliğinde Değişiklik Yapılmasına Dair Tebliğ, T.C. Resmi Gazete, 28976, 18.04.2014. Erişim Tarihi: 15.09.2016. http://www.resmigazete.gov.tr/eskiler/2013/03/20130329-4.htm

[6]. EC, Occupational Health and Safety Risks in The Healthcare Sector Guide To Prevention And Good Practice. European Commission, Directorate-General for Employment, Social Affairs and Inclusion, Luxemburg, s. 14-234, (2010).Erişim Tarihi: 01.08.2014 http://bookshop.europa.eu/en/occupationalhealth-and-safety-risks-in-the-healthcare-sector-pbKE3111047/

[7]. İş Sağlığı Ve Güvenliği Risk Değerlendirmesi Yönetmeliği, T.C. Resmi Gazete, 28512, 29.12.2012.Erişim $\quad$ Tarihi: $\quad 15.09 .2016$ http://mevzuat.basbakanlik.gov.tr/Metin.Aspx?MevzuatKod=7.5.16925\&MevzuatIliski=0\&sourceX $\underline{\text { mlSearch }=}$

[8]. SGK, SGK 2014 İstatistik Yillı̆̆1, (2015). Erişim Tarihi: 2.10 .2016 http://www.sgk.gov.tr/wps/portal/tr/kurumsal/istatistikler/sgk_istatistik_yilliklari

[9]. Urhan, B. "Sağlık Sektöründe Kadın Emeğinin Toplumsal Cinsiyet Açısından Analizi”, Çalışma ve Toplum, 2(29): 191-215, (2011).

[10]. İlhan N. M., Özkan S., Kurtcebe Ö. Z., Aksakal N. F., "Gazi Üniversitesi Tıp Fakültesi Hastanesinde Çalışan Araştırma Görevlileri ve Intörn Doktorlarda Şiddete Maruziyet ve Şiddetle İlişkili Etmenler”, Toplum Hekimliği Bülteni, 28(3):15-23, (2009).

[11].Parlar, S. "Sağlık Çalışanlarında Göz Ardı Edilen Bir Durum: Sağlıklı Çalışma Ortamı”, TSK Koruyucu Hekimlik Bülteni, 7(6):547-554, (2008).

[12].Ayrancı Ü., Yenilmez Ç., Günay Y., Kaptanoğlu C., "Çeşitli Sağlık Kurumlarında ve Sağlık Meslek Gruplarında Şiddete Uğrama Sıklığı”, Anadolu Psikiyatri Dergisi, 3(3):147-154, (2002).

[13].Gökçe T., Dündar C., "Samsun Ruh ve Sinir Hastalıkları Hastanesi'nde Çalışan Hekim ve Hemşirelerde Şiddete Maruziyet Sıklığı ve Kaygı Düzeylerine Etkisi”, İnönü Üniversitesi Tıp Fakültesi Dergisi, 15(1): 25-28, (2008).

[14].Erol, S., Özkurt Z., Altoparlak Ü., Parlak M., "Atatürk Üniversitesi Tıp Fakültesi Hastaneleri’nde 2001 Yılında Gözlenen Hastane İnfeksiyonları." Hastane İnfeksiyonları Dergisi 7(3): 153-156, (2003).

[15].Solak S., Abamor Y. M., "Sağlık Çalışanlarında Fiziksel Zorlanma ve Bel Ağrısı Sıklı̆̆ı", sağlık Çalışanlarının Sağlığı 1. Ulusal Kongresi, Ankara, s. 188-190, (1999).

[16].Büker, N., Aslan E., Altuğ F., Cavlak U., "Hekimlerde Kas-İskelet Sistemi Problemlerinin Analizi" Dumlupınar Üniversitesi, Fen Bilimleri Dergisi. 10: 163-71, (2006).

[17].Alaylı G., Canbaz S., Akyol Y., Durmuș D., "Musculoskeletal Disorders Among Physicians in Samsun", Journal of Rheumatology and Medical Rehabilitation, 19(3):132-136, (2008). 